\title{
Symposium on Proteins \& Other Macromolecules: \\ Design and Assessment of Outreach Program
}

ACS Spring 2020 National Meeting

Division of Chemical Education

Oral Paper CHED 120 - B. Ameer, R.A. Weintraub

Barbara Ameer, PharmD, MBA, BCPS, FCP, Adjunct Associate Professor, Rutgers - Robert Wood Johnson

Medical School, New Brunswick NJ

Randy Alan Weintraub, MS, PhD, Senior Adjunct Instructor Rowan College at Burlington, Mt Laurel NJ 


\section{ACS Symposium theme "Protein Chemistry for Life"}

- Community Outreach at Princeton University

- Grants awarded:

- Innovative Project Grant, American Chemical Society

- Small Meeting Grant, The Company of Biologists

Grants written by

Barbara Ameer, PharmD, MBA, BCPS, FCP

Adjunct Associate Professor of Medicine

Rutgers - Robert Wood Johnson Medical School

New Brunswick NJ 
ACS Symposium theme "Protein Chemistry for Life"

- Objective

- Program Design

- Execution

- Assessment 
ACS Symposium theme "Protein Chemistry for Life"

- Objective

- Program Design

- Execution

- Assessment 


\section{Princeton ACS Symposium: Objective}

- Feature chemistry research tools that enlighten study of biology

- Augment educational offerings of ACS Local Section

- Utilize local talent of graduate students and trainees to convey knowledge and excitement about protein chemistry to novices and non-experts 
ACS Symposium theme "Protein Chemistry for Life"

- Objective

- Program Design

- Execution

- Assessment 


\section{Planning: Presenters and Topics}

- Identify researchers at graduate student and post-doctoral levels

- Select topic of personal interest related to protein science

- Identify keynote speaker(s) from academia

- Excellent at communicating principles of protein science

- Willing and motivated to tailor presentation to a general science audience with basic chemistry and biology knowledge 


\section{Planning: Assessment}

Select/create tools to assess the educational program

- Literature review

- Determine whether a suitable (validated) survey is available

- Design tool

- Create written attendee surveys for adult \& student learners, to be completed onsite

- Plan with intent to inform future activities

- Evaluate survey instruments prior to implementi 


\section{Planning: Potential Audiences}

- Advertise to community via campus radio station

- Invite local high school chemistry \& biology educators and their students 
ACS Symposium theme "Protein Chemistry for Life"

- Objective

- Program Design

- Execution

- Assessment

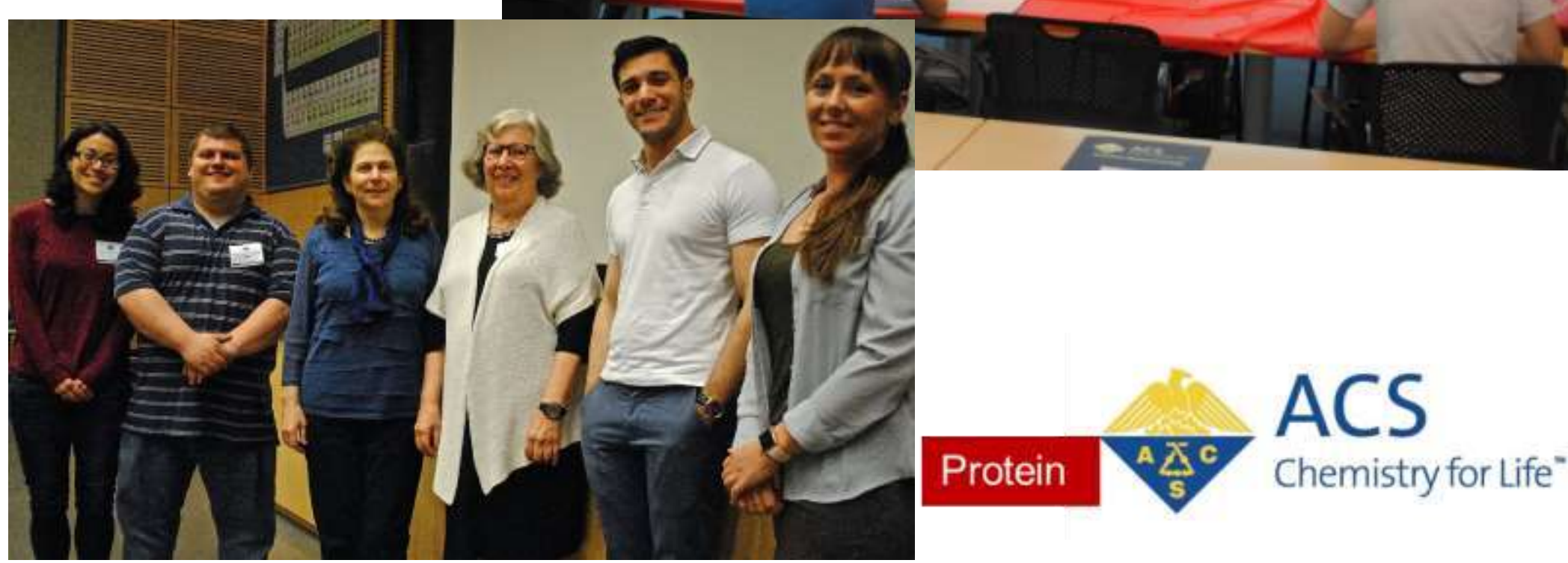




\section{Participants}

- Collectively over 100 students, teachers, community members attended one or more programs offered

- Several local high school chemistry teachers and one biology teacher engaged their students

- Community members were predominately parents of students 


\section{Symposium Presenters}

- PhD expert researchers in protein chemistry delivered keynotes on:

- Protein structure and computational design

- Protein Data Bank (PDB)

- Short talks were delivered by graduate student and post-doctoral trainees conducting protein science investigations 


\section{Selection of Content: Survey Feedback}

\section{- $68 \%$ were interested or strongly interested in topics}

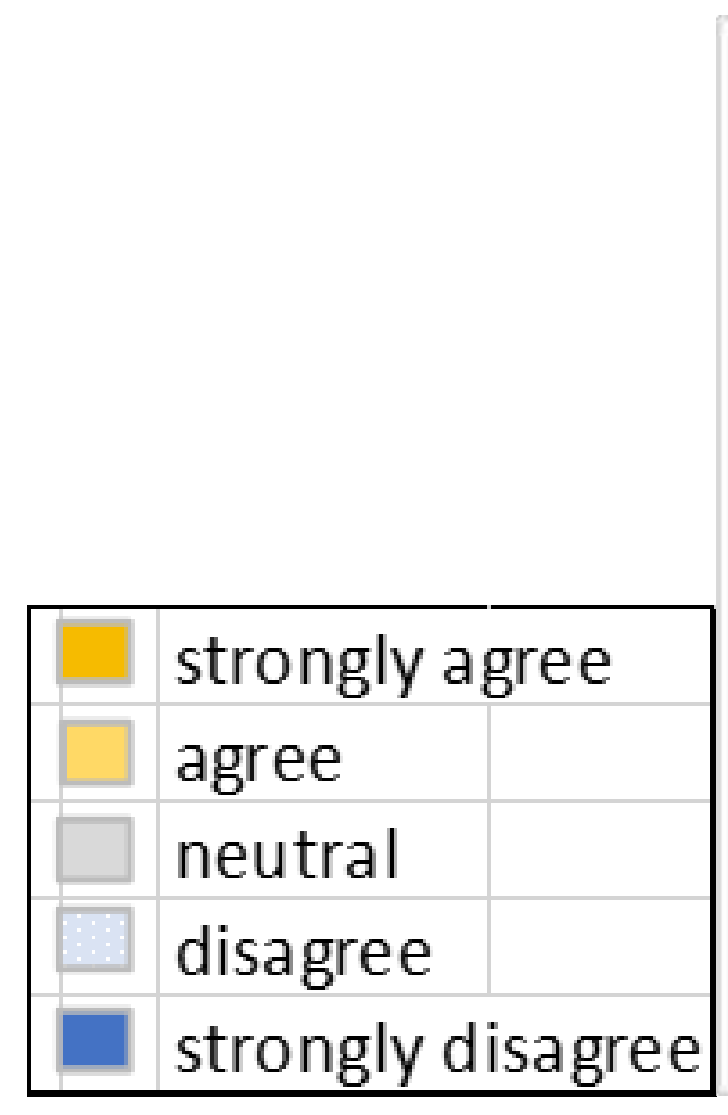

I was interested in many of the topics presented

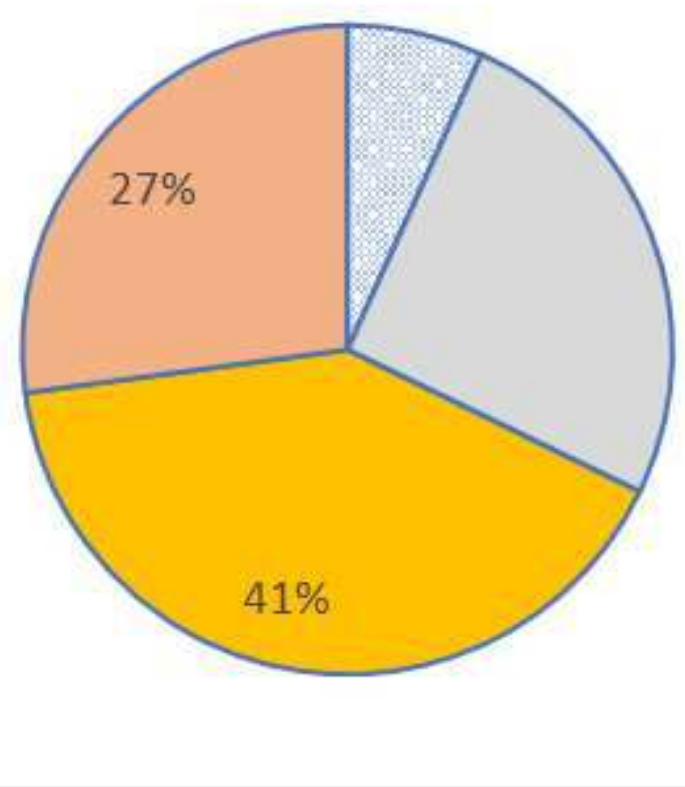

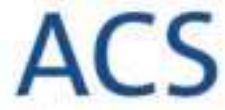

Protein 


\section{Some Topics of Short Talks}

- Design of proteins with new, useful functions

- Protein structure and function

- Protein and RNA crosstalk

- Protein crystallography

- Quantitative proteomic techniques

- Proteins and drug resistance

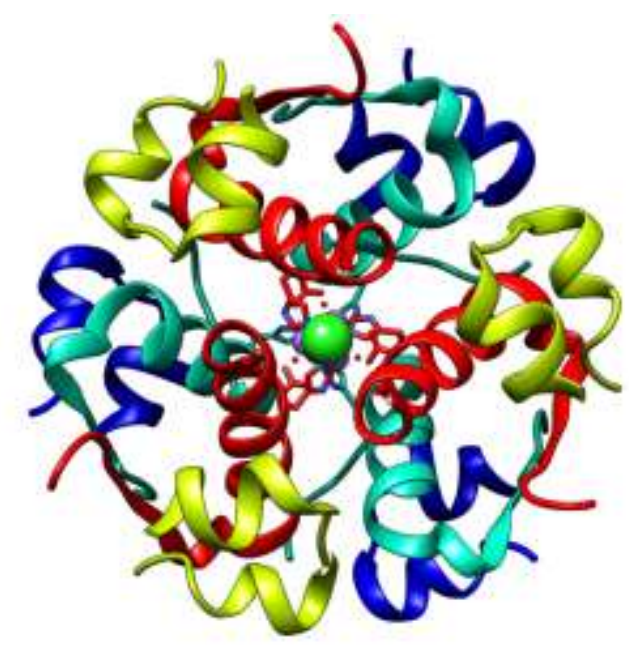

- Enzymes for organic synthesis

- Metals in protein biology

- Amyloid in Alzheimer's disease 


\section{Example Content: Protein Folding \& Misfolding}

"Protein folding is the final step in the information transfer from gene to functional protein, and ... is of fundamental biological importance." -Franz-Ulrich Hartl
Translation

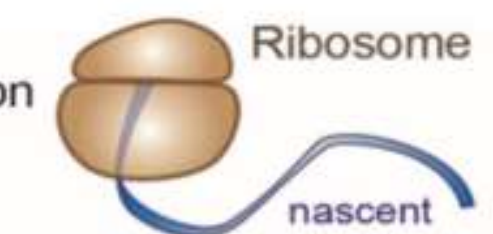

polypeptide

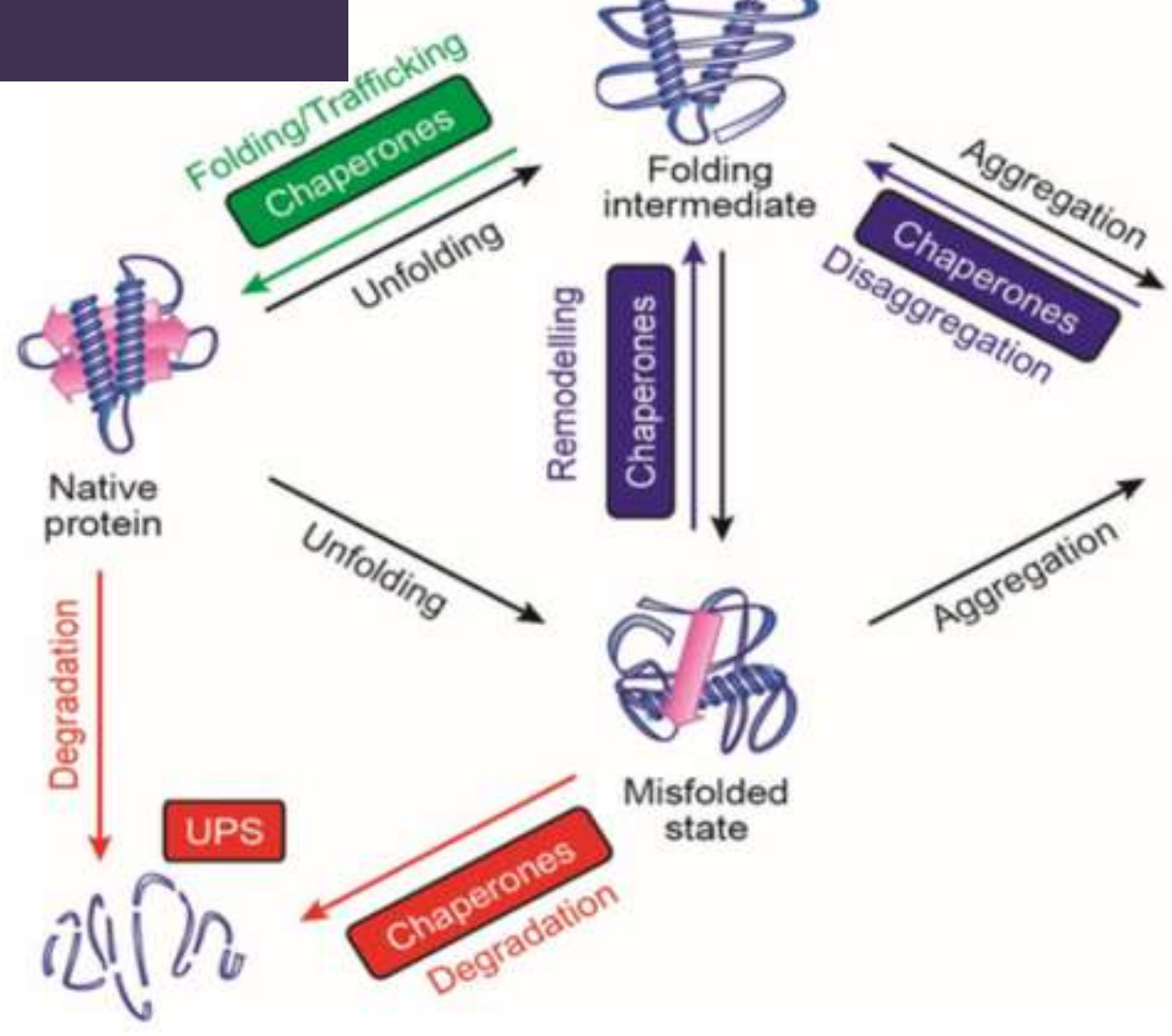

ACS Spring 2020 National Meeting

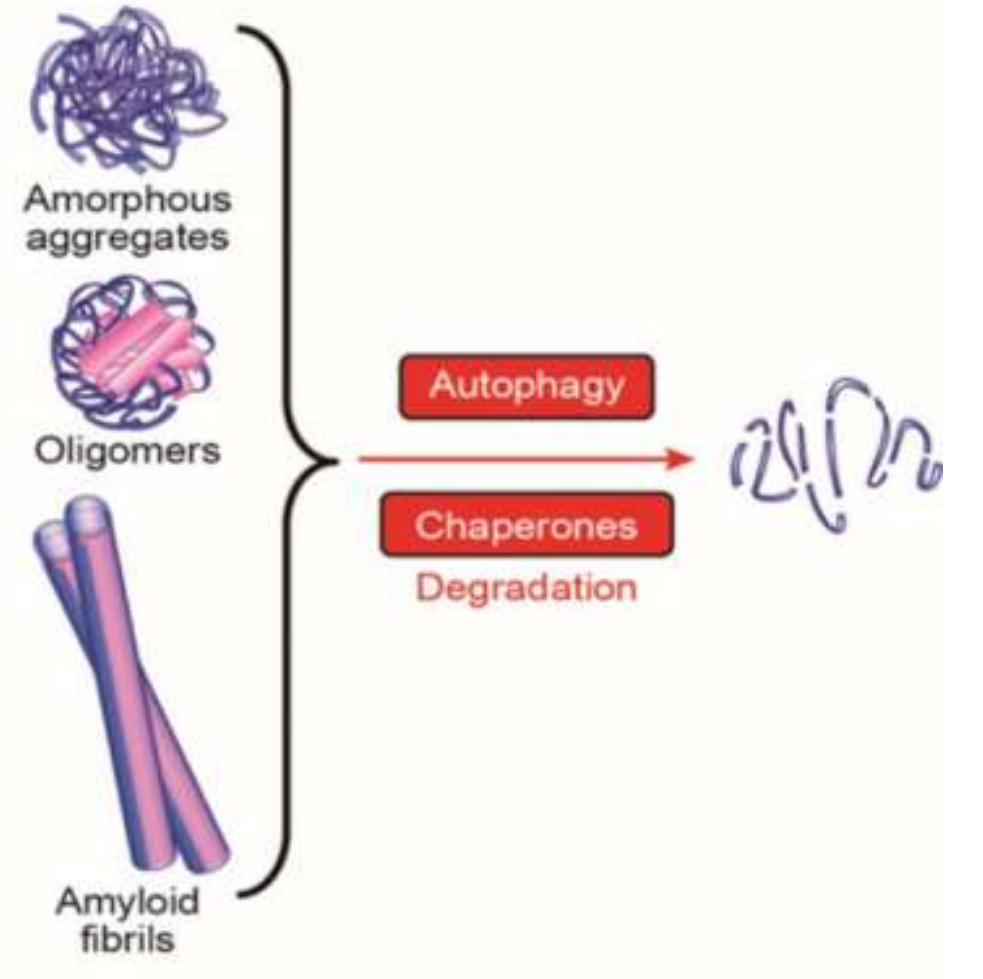




\section{Keynote Content and Learning: PDB}

Memorable learnings, according to student surveys re: worldwide Protein Data Bank (wwPDB)

- Archived 3D structures of $>140,000$ nucleic acids, proteins, macromolecular machines

- An international, collaborative effort

- Freely and globally available

- Database >200 million data file downloads per day worldwide

- Among top 100 scientific sources cited 
ACS Symposium theme "Protein Chemistry for Life"

- Objective

- Program Design

- Execution

- Assessment 


\section{Survey: Qualitative Comments}

- Surveys, verbal feedback $(n=100)$

showed attendees had strong interest in protein science and journey to grad school

- 'It was very interesting to see the different scientists" journey into science and their journey in the lab."

- "Great experience. We can see what we are interested in studying in the future." 


\section{Survey: Main Quantitative Metric}

Willingness to Engage

$63 \%$ of participants strongly agreed or agreed with the statement,

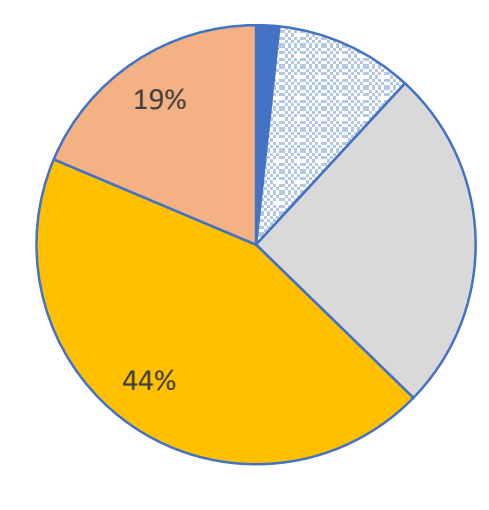

strongly agree

agree

neutral

disagree

strongly disagree

"I am now more likely to be involved in a project or activity involving proteins" 


\section{Assessment of Outcomes: Presenters}

PhD candidate or post-doc presenters

- Two symposium events per year (2018 - 2019) collectively afforded speaking opportunities to more than 15 individuals

- Highest active participation to date from Princeton Chemistry or Molecular Biology Depts in PACS activity, achieved Local Section goal 


\section{Assessment of Outcomes: Qualitative}

- Section Chair, a volunteer at first event, viewed it as an operational success

- Resources (people and space) well-utilized

- Attendance met expectations

- Educator, a former industry PhD biologist, appreciated update on chemistry connections to life science

- Feedback suggests an audience to target in the future 


\section{Princeton ACS Symposium: Accomplishments}

- Informed students, educators \& community members about exciting developments in techniques that advance our understanding of macromolecules important to chemical biology

- Nat'l ACS recognition: Innovative New Program

- ChemLuminary Local Section semi-finalist, 2019

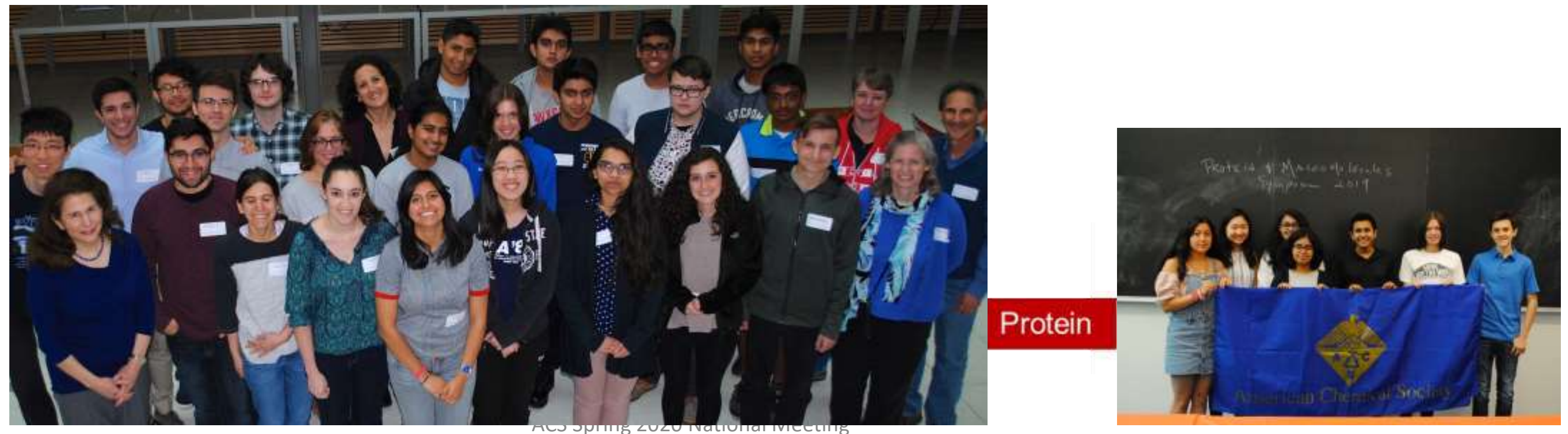


Contact Information

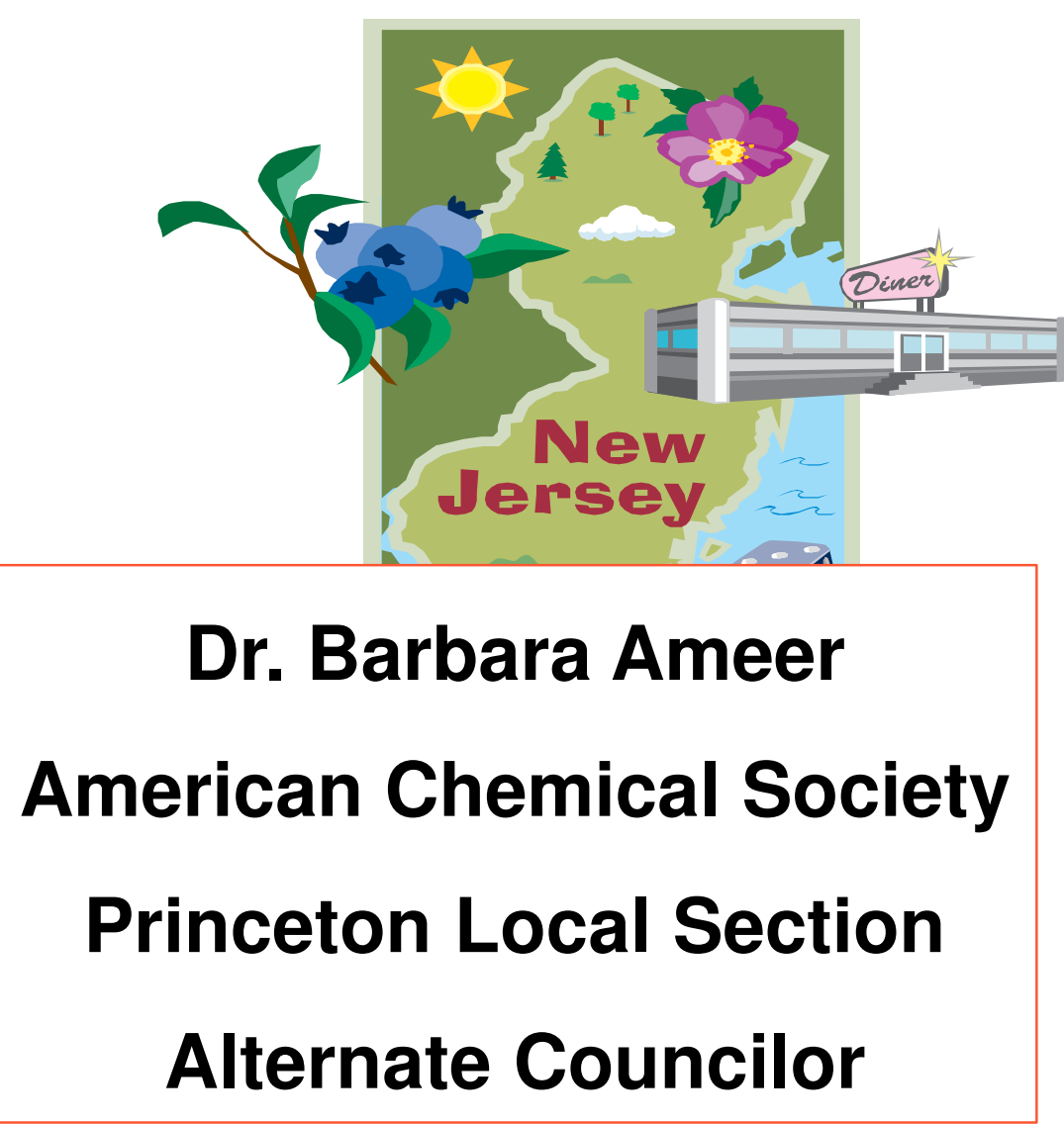

